Pak. j. sci. ind. res. Ser. B: biol. sci. 2018 61B(1) 9-14

\title{
Efficacy of Boron as Foliar Feeding on Yield and Quality Attributes of Maize (Zea mays L.)
}

\author{
Muhammad Tahir ${ }^{\mathrm{a}}$, Waqas Shehzad ${ }^{\mathrm{a}}$, Muhammad Aqeel Sarwar ${ }^{\mathrm{ab} *}$, \\ Sajid Hussain ${ }^{\text {ac }}$ and Muhammad Imran ${ }^{\mathrm{b}}$ \\ ${ }^{a}$ Department of Agronomy, University of Agriculture, Faisalabad, Pakistan \\ ${ }^{b}$ Crop Sciences Institute, National Agricultural Research Centre, Islamabad, Pakistan \\ ${ }^{\mathrm{c} C}$ College of Agriculture, Bahauddin Zakariya University, Bahadur Sub Campus, Layyah, Pakistan
}

(received December 19, 2016; revised March 10, 2017; accepted April 18, 2017)

\begin{abstract}
Boron being an essential micronutrient plays a vital role in improving crop productivity and quality. Therefore a field study was conducted at agronomic research area, University of Agriculture, Faisalabad, Pakistan, during spring season 2014, to evaluate the effect of boron as foliar application on yield and quality of maize. The experiment was laid out in randomized complete block design with three repeats. There were nine treatments in the experiment including a control treatment, four treatments of foliar sprays of $0.5 \%$ borax and four treatments of water sprays (without borax) with different time intervals. Statistical analysis revealed that use of boron significantly affected maize yield and quality and the application of boron with three foliar sprays of $0.5 \%$ borax had significant positive effect on most of yield contributing parameters, giving plant height $(217.00 \mathrm{~cm})$, cob length $(15.81 \mathrm{~cm})$, cob diameter $(6.10 \mathrm{~cm})$, cob weight (147.00 g), number of grains per cob (481.00), 1000 grain weight (333 g), grain yield (5.26 t/ha), biological yield (14.75 t/ha) and harvest index (35.66\%). However in case of quality, four foliar sprays of $0.5 \%$ borax displayed better results by producing higher seed protein $(10.06 \%)$ and oil contents (4.72\%), respectively. From the results of experiment it can be concluded that three foliar sprays of $0.5 \%$ boron triggers yield attributes while four foliar sprays of $0.5 \%$ boron encourages qualitatively to maize crop.
\end{abstract}

Keywords: maize, boron, foliar application, yield

\section{Introduction}

Maize (Zea mays L.) being the highest yielding cereal crop in the world after wheat and rice holds a prominent position in major crops. In Pakistan it is cultivated in all the provinces, with Punjab and Khyber Pakhtunkhwa being the major producers. It fits well in our cropping system due to higher yield potential, short duration, high net economic return and ability to grow in varying environments (Shahzad et al., 2012). Being a multipurpose crop for food, feed and fodder; currently, except potato, maize is the most profitable and dependable crop in our agriculture system. At present 1.13 million hectares are utilized for maize cultivation in Pakistan with total production of 4.69 million tonnes and an average grain yield of $4.15 \mathrm{t} / \mathrm{ha}$ (GOP, 2014). Although the soil and climatic conditions of Pakistan are favorable for maize production, but per hectare yield is very low as compared to other maize growing countries of the world. Low yield of maize in Pakistan is due to many constraints but among them, poor plant nutrition (micronutrients), traditional sowing methods and lack

*Author for correspondence; E-mail: maqeeluaf@gmail.com of optimal crop stand are the factors of prime importance (Ahmad et al., 2011; Alias et al., 2008).

Various micronutrients including boron and their application methods have significant effect on growth and yield of different crops (Nadim et al., 2013; Ahmad et al., 2012). However, maize is the kind of crop especially sensitive to micronutrients deficiency and definite quantity of micronutrients is indispensable for its proper growth and development (Ziaeyan and Rajaie, 2009). Boron is one of those micronutrients which are rapidly being deficient in soils. It is needed in small amount but proved essential micronutrient for plant growth. Its deficiency symptoms and nutritional disorder characteristics appear when plant faces reduced supplies of boron (Leghari et al., 2016). Boron impacts transport of carbohydrates, cell division, cell wall strength and development, onset of fruits and seed development and hormonal production (Gunes et al., 2003). Its severe deficiency causes abnormal development of reproductive organs and ultimately results in reduction of plant yield (Rashid et al., 2004). Boron is able to mitigate the drought effects as explained by Davis et al. (2003) and its application improved the parameters of the main 
yield components, thus increasing yield level and enriching the chemical composition of crops.

Boron can be used as soil and foliar applications on growing crop. Foliar application of boron is believed to retain significant carbohydrate phloem mobility to flowering meristematic cell from either senescing leaves/bark. Thus foliar spray of boron is not only a source to apply boron at a particular growth stage but also permits a rapidly-acting action to mitigate the problem soon after the deficiency diagnosis (Shahzad et al., 2012). Therefore, the present study was conducted to elucidate the effect of boron as foliar application on yield and quality of maize under Faisalabad conditions.

\section{Materials and Methods}

The experiment was conducted at the research area of Agronomy Department, University of Agriculture, Faisalabad, Pakistan, during spring 2014. The experimental area is located between $30.35-31.47^{\circ} \mathrm{N}$ latitude and $72.08-73^{\circ} \mathrm{E}$ longitude at an elevation of $150 \mathrm{~m}$ above the sea level. The experiment was carried in randomized complete block design with triplicate run and a net plot size of $5 \times 4.20 \mathrm{~m}$. Experimental treatments was performed as:

$$
\begin{aligned}
\mathrm{T}_{0}= & \text { Control (no water and boron spray) } \\
\mathrm{T}_{1}= & \text { One water spray at } 4-5 \text { leaves stage }(\mathrm{V} 4-\mathrm{V} 5 \\
& \text { stage }) \\
\mathrm{T}_{2}= & \text { One foliar spray of } 0.5 \% \text { borax }\left(\mathrm{Na}_{2} \mathrm{~B}_{4} \mathrm{O}_{7} \cdot 10 \mathrm{H}_{2} \mathrm{O}\right) \\
& \text { at } 4-5 \text { leaves stage } \\
\mathrm{T}_{3}= & \text { Two water sprays }\left(1^{\text {st }} \text { at } 4-5\right. \text { leaves stage and } \\
& 2^{\text {nd }} \text { with one week interval) } \\
\mathrm{T}_{4}= & \text { Two foliar sprays of } 0.5 \% \text { borax }\left(1^{\text {st }} \text { at } 4-5\right. \\
& \text { leaves stage and } 2^{\text {nd }} \text { with one week } \\
& \text { interval }) \\
\mathrm{T}_{5}= & \text { Three water sprays }\left(1^{\text {st }} \text { at } 4-5 \text { leaves stage, } 2^{\text {nd }}\right. \\
& \text { and } \left.3^{\text {rd }} \text { with one week interval }\right) \\
\mathrm{T}_{6}= & \text { Three foliar sprays of } 0.5 \% \text { borax }\left(1^{\text {st }} \text { at } 4-5\right. \\
& \text { leaves stage, } 2^{\text {nd }} \text { and } 3^{\text {rd }} \text { with one week } \\
& \text { interval }) \\
\mathrm{T}_{7}= & \text { Four water sprays }\left(1^{\text {st }} \text { at } 4-5 \text { leaves stage, } 2^{\text {nd }},\right. \\
& \left.3^{\text {rd }} \text { and } 4^{\text {th }} \text { with one week interval }\right) \\
\mathrm{T}_{8}= & \text { Four foliar sprays of } 0.5 \% \text { borax }\left(1^{\text {st }} \text { at } 4-5\right. \\
& \text { leaves stage, } 2^{\text {nd }}, 3^{\text {rd }} \text { and } 4^{\text {th }} \text { with one } \\
& \text { week interval }) .
\end{aligned}
$$

Composite soil samples were collected at a depth of $30 \mathrm{~cm}$. then air dried, crushed, and tested for physical and chemical properties of soil. The research field had a clay loam soil, having soil pH (7.7), O.M (0.88\%),
E.C $(2.4 \mathrm{~d} / \mathrm{Sm}), \mathrm{N}(0.21 \%), \mathrm{P}(13.2 \mathrm{mg} / \mathrm{kg}), \mathrm{K}(174.5$ $\mathrm{mg} / \mathrm{kg}$ ) and $\mathrm{B}(0.2 \mathrm{mg} / \mathrm{kg})$. Maize hybrid "Monsanto$6525^{\prime}$ "was used as test crop. Sowing was done on $10^{\text {th }}$ February, 2011 with the help of hand drill at $70 \mathrm{~cm}$ spaced rows using seed rate of $25 \mathrm{~kg} / \mathrm{ha}$. Fertilizer was applied@250-125-125 kg/NPK/ha. Half of N and whole of $\mathrm{P}$ and $\mathrm{K}$ were applied at sowing in the form of urea, diammonium phosphate and sulphate of potassium, respectively, while remaining nitrogen was applied in splits. Boron fertilizer as borax $(11 \% \mathrm{~B})$ was applied per treatment and the volume of water used for each boron foliar spray was @ 250 L/ha. Crop was kept weed free by hoeing twice to avoid weed-crop competition. Insect pest were kept under the threshold level through chemical control. For this purpose Furadon was applied@ $20 \mathrm{~kg} / \mathrm{ha}$ after first irrigation to control stem borer and shoot fly. All agronomic practices except those under study were kept normal and uniform for all the treatments. The crop was harvested manually 115 days after sowing at its physiological maturity on $15^{\text {th }}$ of June 2014 . Ten plants were selected at random at harvest from each plot for sampling and observations regarding plant height at maturity $(\mathrm{cm})$, cob length $(\mathrm{cm})$, cob diameter $(\mathrm{cm})$, cob weight $(\mathrm{g})$, number of grains per cob were noted and then averaged for recording mean of these parameters. Similarly, from the seed lot of every plot, five samples, each of 1000 grains were randomly taken, recorded their weight and then mean 1000 achene weight was computed. The grain yield and biological yield were taken on plot basis for each treatment, averaged and then converted to $\mathrm{kg} / \mathrm{ha}$. While harvest index was computed as the ratio of achene yield to biological yield and calculated as follows:

Harvest index $(\%)=$ Achene yield/biological yield $\times 100$

Data collected was statistically analyzed using Fisher's analysis of variance technique and treatment's means were compared by LSD at 0.05 probability (Steel et al., 1997).

\section{Results and Discussion}

Maize yield attributes. Data regarding yield attributes of maize crop as affected by boron foliar applications are presented in Table 1-2. Significant increase in plant height was observed by boron supplement $(\mathrm{P} \leq 0.05)$. Maximum plant height $(217.00 \mathrm{~cm})$ was measured in $\mathrm{T}_{6}$ (three foliar sprays of $0.5 \%$ borax) followed by $\mathrm{T}_{4}$ (two foliar sprays of $0.5 \%$ borax) and $\mathrm{T}_{8}$ (four foliar sprays of $0.5 \%$ borax) with plant height $214.00 \mathrm{~cm}$ and 
$212.33 \mathrm{~cm}$, respectively, which were statistically significant as compared to $T_{1}$ (control) measuring plant height $(197.67 \mathrm{~cm})$. The improvement in plant height due to application of boron might be, because it increased the internodal length of plant by increasing number of cells as it is known that the boron is associated with the development of cell wall and cell differentiation and hence, helps in root elongation and shoot growth of plant (Shehzad and Maqsood, 2015). Similar findings have also been described by Tombo et al. (2008) who stated that plant height was positively and significantly affected by boron applications.

Comparison of treatment means $(\mathrm{P} \leq 0.05)$ showed significant effects of boron feeding on cob length. Largest cob length $(15.81 \mathrm{~cm})$ was recorded in $\mathrm{T}_{6}$ (three foliar sprays of $0.5 \%$ borax) which was statistically at par with $\mathrm{T}_{4}$ (two foliar sprays of $0.5 \%$ borax) having cob length $15.77 \mathrm{~cm}$, while the treatments $\mathrm{T}_{8}$ (four foliar sprays of $0.5 \%$ borax) and $\mathrm{T}_{2}$ (one foliar spray of $0.5 \%$ borax) devising cob length $(15.40 \mathrm{~cm}$ and $15.35 \mathrm{~cm}$, respectively) were followed by $\mathrm{T}_{4}$. However, the smallest length of cob $(14.21 \mathrm{~cm})$ was recorded in $\mathrm{T}_{0}$ (control), where no water and boron spray was applied. The increase in cob size by boron application was because of its role in cell division, expansion and other physiological processes like, inhibiting the unnecessary conversion of sugars into starch which is essential for cob development. These results are in strong line with Tahir et al. (2012) who reported similar findings for cob development.

The statistics regarding the cob length displayed $(\mathrm{P} \leq 0.05)$, larger cob diameter in all boron foliar applied treatments. Maximum cob diameter $(6.10 \mathrm{~cm})$ was resulted in $\mathrm{T}_{6}$ (three foliar sprays of $0.5 \%$ borax) tracked by $\mathrm{T}_{4}$ (two foliar sprays of $0.5 \%$ borax), $\mathrm{T}_{8}$ (four foliar sprays of $0.5 \%$ borax) and $\mathrm{T}_{2}$ (one foliar spray of $0.5 \%$ borax) having cob diameter $(6.04 \mathrm{~cm}) ;(6.00 \mathrm{~cm})$ and $(5.95 \mathrm{~cm})$, respectively with no significant difference

Table 1. Mean square values for boron as foliar application on yield attributes of maize (Zea mays L.)

\begin{tabular}{|c|c|c|c|c|c|c|c|c|c|c|}
\hline \multirow[t]{2}{*}{ Source of variation } & \multirow[t]{2}{*}{ Df } & \multicolumn{9}{|c|}{ Mean square } \\
\hline & & $\overline{\mathrm{PH}}$ & $\mathrm{CL}$ & $\mathrm{CD}$ & $\mathrm{CW}$ & GNPC & TGW & GY & BY & HI \\
\hline Replication (R) & 2 & 28.58 & 0.007 & 0.07 & 0.074 & 3.370 & 114 & 0.00021 & 0.002 & 0.027 \\
\hline Treatments (T) & 8 & $1036.88^{* *}$ & 0.997 & 0.96 & $650.7^{* *}$ & $854.6^{* *}$ & $456.99^{* *}$ & 0.0728 & 0.217 & 0.575 \\
\hline Error $(\mathrm{R} \times \mathrm{T})$ & 16 & 423.24 & 0.002 & 0.03 & 84.59 & 6.87 & 49.43 & 0.0009 & 0.0005 & 0.047 \\
\hline Total & 26 & & & & & & & & & \\
\hline
\end{tabular}

** = means significance at $\mathrm{P} \leq 0.05$ level of probability.

Table 2. Effect of boron as foliar application on yield attributes of maize (Zea mays L.)

\begin{tabular}{|c|c|c|c|c|c|c|c|c|c|}
\hline \multirow[t]{3}{*}{ Treatments } & \multicolumn{3}{|c|}{ Parameters } & \multirow{3}{*}{ CW (g) } & \multirow{3}{*}{ GNPC } & \multirow{3}{*}{ TGW } & & & \multirow{3}{*}{ HI (\%) } \\
\hline & $\mathrm{PH}$ & $\mathrm{CL}$ & $\mathrm{CD}$ & & & & GY & BY & \\
\hline & \multicolumn{3}{|c|}{$(\mathrm{cm})$} & & & & \multicolumn{2}{|c|}{$(\mathrm{kg} / \mathrm{ha})$} & \\
\hline $\mathrm{T}_{0}=$ Control & $197.67 d$ & $14.21 \mathrm{~g}$ & $5.50 \mathrm{e}$ & $132.00 \mathrm{f}$ & $435.00 \mathrm{f}$ & $295.33 \mathrm{e}$ & $4.82 \mathrm{f}$ & $13.95 \mathrm{~g}$ & $34.55 \mathrm{e}$ \\
\hline $\mathrm{T}_{1}=$ One water spray & $201.45 \mathrm{~cd}$ & $14.40 \mathrm{f}$ & $5.63 \mathrm{de}$ & $134.00 \mathrm{ef}$ & $439.00 \mathrm{f}$ & $304.67 \mathrm{de}$ & $4.87 \mathrm{f}$ & $14.08 \mathrm{f}$ & $34.59 \mathrm{e}$ \\
\hline $\mathrm{T}_{2}=$ One spray of $0.5 \%$ borax & $208.67 \mathrm{abc}$ & $15.35 b$ & $5.95 \mathrm{abc}$ & $141.67 b c$ & $466.33 \mathrm{c}$ & $320.00 \mathrm{bc}$ & $5.15 \mathrm{c}$ & $14.56 \mathrm{c}$ & $35.37 \mathrm{abc}$ \\
\hline $\mathrm{T}_{3}=$ Two water sprays & $201.78 \mathrm{~cd}$ & $14.61 \mathrm{e}$ & $5.70 \mathrm{~d}$ & $136.33 \mathrm{def}$ & $448.00 \mathrm{e}$ & $306.67 \mathrm{de}$ & $4.95 \mathrm{e}$ & $14.25 \mathrm{e}$ & $34.74 \mathrm{de}$ \\
\hline $\mathrm{T}_{4}=$ Two sprays of $0.5 \%$ borax & $214.00 \mathrm{ab}$ & $15.77 \mathrm{a}$ & $6.04 \mathrm{ab}$ & $146.00 \mathrm{a}$ & $477.00 \mathrm{ab}$ & $328.00 \mathrm{ab}$ & $5.21 \mathrm{ab}$ & $14.63 b$ & $35.61 \mathrm{a}$ \\
\hline $\mathrm{T}_{5}=$ Three water sprays & $202.67 \mathrm{~cd}$ & $14.90 \mathrm{~d}$ & $5.80 \mathrm{~cd}$ & $138.33 \mathrm{~cd}$ & $452.00 \mathrm{de}$ & $309.33 \mathrm{~cd}$ & $5.00 \mathrm{de}$ & $14.28 \mathrm{de}$ & $35.01 \mathrm{~cd}$ \\
\hline $\mathrm{T}_{6}=$ Three sprays of $0.5 \%$ borax & $217.00 \mathrm{a}$ & $15.81 \mathrm{a}$ & $6.10 \mathrm{a}$ & $147.00 \mathrm{a}$ & $481.00 \mathrm{a}$ & $333.00 \mathrm{a}$ & $5.26 \mathrm{a}$ & $14.75 \mathrm{a}$ & $35.66 \mathrm{a}$ \\
\hline $\mathrm{T}_{7}=$ Four water sprays & $205.67 \mathrm{bcd}$ & $15.00 \mathrm{c}$ & $5.90 \mathrm{bc}$ & $139.00 \mathrm{~cd}$ & $455.00 \mathrm{~d}$ & $312.00 \mathrm{~cd}$ & $5.05 \mathrm{~d}$ & $14.30 \mathrm{~d}$ & $35.21 \mathrm{bc}$ \\
\hline $\mathrm{T}_{8}=$ Four sprays of $0.5 \%$ borax & $212.33 \mathrm{ab}$ & $15.40 \mathrm{~b}$ & $6.00 \mathrm{ab}$ & $144.00 \mathrm{ab}$ & $475.00 \mathrm{~b}$ & $324.83 \mathrm{ab}$ & $5.18 \mathrm{bc}$ & $14.58 \mathrm{c}$ & $35.53 \mathrm{ab}$ \\
\hline LSD $(P \leq 0.05)$ & 8.9024 & 0.0691 & 0.1996 & 3.9799 & 4.5369 & 12.169 & 0.0522 & 0.0391 & 0.3761 \\
\hline
\end{tabular}

$\mathrm{PH}=$ plant height; $\mathrm{CL}=$ cob length; $\mathrm{CD}=$ cob diameter; $\mathrm{CW}=$ cob weight; $\mathrm{GNPC}=$ grains number per cob; $\mathrm{TGW}=$ thousand grain weight; $\mathrm{GY}=$ grain yield; $\mathrm{BY}=$ biological yield; $\mathrm{HI}=$ harvest index; any two means not sharing a letter in common differ significantly at $\mathrm{P} \leq 0.05$. 
$(\mathrm{P} \leq 0.05)$, whereas the smallest cob diameter $(5.50 \mathrm{~cm})$ was noted from $\mathrm{T}_{0}$ (control). Almost similar date fashion was recorded for cob weight depicting that treatments $\mathrm{T}_{6}$ (three foliar sprays of $0.5 \%$ borax), $\mathrm{T}_{4}$ (two foliar sprays of $0.5 \%$ borax) and $\mathrm{T}_{8}$ (four foliar sprays of $0.5 \%$ borax) measured statistically same cob weight (147.00 g; $146.00 \mathrm{~g} ; 144.00 \mathrm{~g}$, respectively) but different from that of $\mathrm{T}_{0}$ (control) with cob weight $(132 \mathrm{~g})$. The improvement in cob diameter might be due enhanced cell division and cell expansion, whereas increase in cob weight was because of increased cob length and diameter of maize that was attained by the foliar application of boron. The results showed a similarity to the work done by Pasha et al. (2002).

The individual comparison of treatments means $(\mathrm{P} \leq 0.05)$ elucidated that highest number of grains per cob (481.00) was noted in $\mathrm{T}_{6}$ (three foliar sprays of $0.5 \%$ borax) being statistically similar with $\mathrm{T}_{4}$ (two foliar sprays of $0.5 \%$ borax) that devised (477.00) grains number per cob, while the lowest (435.00) was noted in $\mathrm{T}_{0}$ (control). The increase in number of grains per cob might be due to reason that boron application improves the grain setting by improving the grain filling process and reducing the male sterility, often observed in boron deficient conditions. These results are reassuring to the conclusions made by Sultana et al. (2015) and Ahmad et al. (2000).

1000 -grain weight statistics $(\mathrm{P} \leq 0.05)$ evidenced that the treatment, $\mathrm{T}_{6}$ (three foliar sprays of $0.5 \%$ borax) fashioned the maximum 1000-grain weight $(333.00 \mathrm{~g})$. It was trailed by $\mathrm{T}_{4}$ (two foliar sprays of $0.5 \%$ borax) that was statistically at par with $\mathrm{T}_{8}$ (four foliar sprays of $0.5 \%$ borax $)$ by giving (328.00 g) and (324.83 g), respectively while minimum 1000 -grain weight $\left(295.33 \mathrm{~g}\right.$ ) was found in $\mathrm{T}_{0}$ (control). The increase in 1000 -grain weight by foliar application of boron was because, the presence of boron in plant, regulates the translocation of assimilates to grain, as boron sustains the proper functioning of enzymes and integrity of plasma membrane that drops starch contents in leaves and promotes photosynthates translocation towards seeds, finally enhancing 1000-achene weight (Arif et al., 2006). These results are similar with the findings of Tahir et al. (2009) who reported that 1000-grain weight was increased by boron application. Similarly, Khan et al. (2006) and Hussain and Yasin (2004) recorded significant increase in 1000-grain weight with foliar application of micronutrients especially boron.
The efficiency of foliar application of boron is ultimately determined by the level of grain yield per hectare, which in turn is a function of cumulative behavior of all the yield components. Comparison of treatments means $(\mathrm{P} \leq 0.05)$ revealed that the statistically supreme grain yield (5.26 t/ha) was observed in $\mathrm{T}_{6}$ (three foliar sprays of $0.5 \%$ borax) which was at par with $\mathrm{T}_{4}$ (two foliar sprays of $0.5 \%$ borax) producing grain yield $5.21 \mathrm{t} / \mathrm{ha}$, whereas $\mathrm{T}_{0}$ (control) provided least grain yield of $4.82 \mathrm{t} / \mathrm{ha}$. Improved grain yield with boron nutrition was due to its imperative role in pollen germination, proper seed setting, sugar metabolism and balance between net photosynthetic rate and respiration (Khan et al., 2006). These findings are in accordance with that of Nadim et al. (2011).

Boron foliar application also showed significant difference $(\mathrm{P} \leq 0.05)$ in case of biological yield as the highest total biomass $(14.75 \mathrm{t} / \mathrm{ha})$ was obtained from those plots where $T_{6}$ (three foliar sprays of $0.5 \%$ borax) was applied, followed by $\mathrm{T}_{4}$ (two foliar sprays of $0.5 \%$ borax) producing (14.63 t/ha) biological yield. However, $\mathrm{T}_{8}$ (four foliar sprays of $0.5 \%$ borax) and $\mathrm{T}_{2}$ (one foliar sprays of $0.5 \%$ borax) were statistically at par with each other, while lowest biological yield (13.95 t/ha) was recorded in $\mathrm{T}_{0}$ (control). The improvement in biological yield might be due to enhanced plant height, cob length, cob diameter, 1000-grain weight and grain yield by increasing the cell division, cell elongation, pollen tube germination and other physiological processes (Tombo et al., 2008). The results are supported by Ziaeyan and Rajaie (2009) as they found that foliar application of boron increased biological yield in maize.

The data pertaining to harvest index revealed maximum harvest index $(35.66 \%)$ in $\mathrm{T}_{6}$ (three foliar sprays of $0.5 \%$ borax) though, it was statistically similar with $\mathrm{T}_{4}$, $\mathrm{T}_{8}$ and $\mathrm{T}_{2}$ (two, four and one foliar sprays of $0.5 \%$ borax) by documenting (35.61\%, 35.53 and $35.37 \%$ ) harvest index, respectively. While minimum (34.55\%) was recorded where no water and boron spray $\left(\mathrm{T}_{0}\right)$ was applied $(\mathrm{P} \leq 0.05)$. The maximum harvest index in treatment $\mathrm{T}_{6}$ (three foliar sprays of $0.5 \%$ borax) was due to the reason that grain and biological yields were maximum in this treatment that directly affected the harvest index. The improvement in harvest index as a result of boron application might be due to the enhanced photosynthetic and metabolic activity which leads to an increase in various plant pathways responsible for stimulation of plant growth, accumulation of biomass 
and resultantly the harvest index. These results are similar with the outcomes of Tombo et al. (2008) and Alam et al. (2000).

Maize quality attributes. Quality attributes data revealed significant $(\mathrm{P} \leq 0.05)$ effects of different boron applications. In case of seed protein contents (Fig. 1) highest $(10.06 \%)$ was obtained from those plots which were treated with $\mathrm{T}_{8}$ (four foliar sprays of $0.5 \%$ borax) trailed by $\mathrm{T}_{6}$ (three foliar sprays of $0.5 \%$ borax) and $\mathrm{T}_{4}$ (two foliar sprays of $0.5 \%$ borax) that fashioned seed protein $(9.80 \%, 9.53 \%$, respectively). However, lowest protein contents $(8.13 \%)$ was recorded from $\mathrm{T}_{0}$ (control) plots. The increase in protein contents with foliar application of boron was due to the reason that as it enhanced the nitrogen uptake rate, and nitrogen being the essential part of amino group is the building block of proteins.

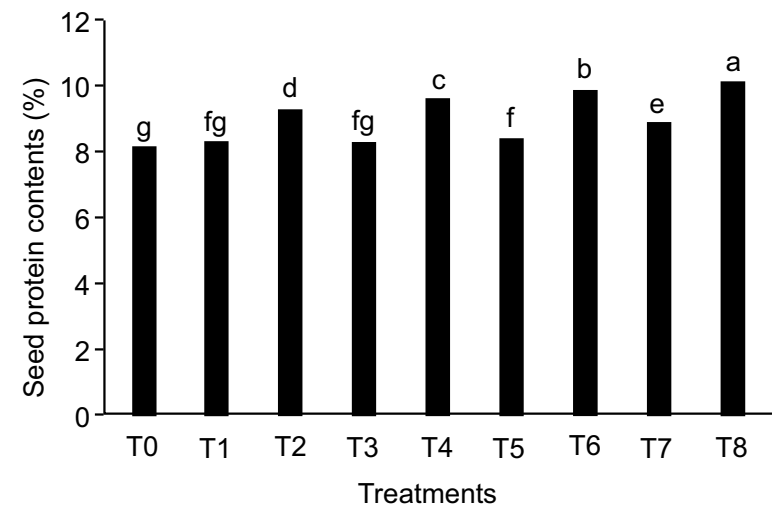

Fig. 1. Effect of boron as foliar application on seed protein contents of maize.

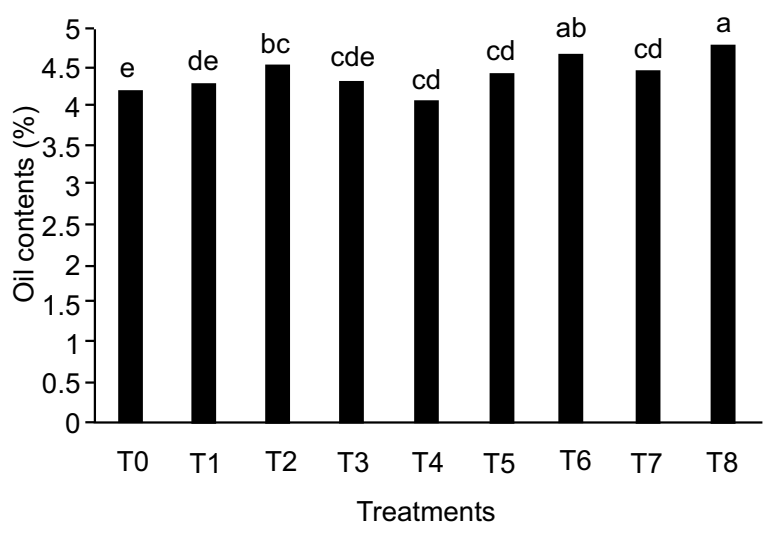

Fig. 2. Effect of boron as foliar application on seed oil contents of maize.
These results are in line with the findings of Malhi et al. (2006). Similar results had also been reported by Dwivedi et al. (2002) as he described significantly increased protein contents with the foliar application of boron.

Seed oil contents of maize presented in Fig. 2 revealed that the maximum seed oil content $(4.72 \%)$ was recorded in maize treated with $\mathrm{T}_{8}$ (four foliar sprays of $0.5 \%$ borax) which was statistically at par with $\mathrm{T}_{6}$ (three foliar sprays of $0.5 \%$ borax) having seed oil content $4.65 \%$. While the minimum seed oil content $(4.17 \%)$ was recorded in $\mathrm{T}_{0}$ (control). These results supported the work of Ahmad et al. (2000) as they stated that foliar application of boron improved seed oil contents.

\section{Conclusion}

On the basis of results it was concluded that maize crop should preferably be fertilized @ three foliar sprays of $0.5 \%$ borax; $1^{\text {st }}$ at $4-5$ leaves stage, $2^{\text {nd }}$ and $3^{\text {rd }}$ with one week interval, along with recommended dose of other fertilizer nutrients to realize higher and supportable production.

\section{References}

Ahmad, A., Tahir, M., Ehsan Ullah, M., Naeem, M., Ayub, M., Rehman, H., Talha, M. 2012. Effect of silicon and boron foliar application on yield and quality of rice. Pakistan Journal of Life and Social Sciences, 10: 161-165.

Ahmad, A., Khan, I. 2000. Effect of boron fertilization on oil accumulation, acetyl-CoA concentration and acetyl-CoA carboxylase activity in the developing seeds of rapeseed (Brassica campestris L.). Australian Journal of Agricultural Research, 5: 1023-1029.

Ahmad, S.Q., Ghaffar, M., Ahmad, F. 2011. Genetic diversity analysis for yield and other parameters in maize (Zea mays L.) genotypes. Asian Journal of Agricultural Sciences, 3: 385-388.

Alam, S.M., Iqbal, Z., Latif, A. 2000. Effect of boron application with or without zinc on the yield of wheat. Pakistan Journal of Soil Science, 18: $95-$ 98.

Alias, M.A., Bukhsh, H.A., Ahmad, R., Cheema, Z.A., Ghafoor, A. 2008. Production potential of three maize hybrids as influenced by varying plant density. Pakistan Journal of Agricultural Sciences, 45: 413-417.

Arif, M., Chohan, M.A., Ali, S., Gul, R., Khan, S. 2006. 
Response of wheat to foliar application of nutrients. Journal of Agriculture and Biological Sciences, 1: 30-34.

Davis, J.M., Sanders, D.C., Nelson, P.V. 2003. Boron improves growth, yield, quality and nutrient content of tomato. Journal of The American Society for Horticultural Science, 128: 441-446.

Dwivedi, S.K., Singh, R.S., Dwivedi, K.N. 2002. Effect of sulphur and zinc nutrition on yield and quality of maize in typic ustochrept soil of Kanpur. Journal of Indian Society of Soil Science, 50: 70-74.

GOP, 2014. Economic Survey of Pakistan 2014-2015. Finance and Economic Affairs Division, Government of Pakistan, Islamabad, Pakistan, pp. 15.

Gunnes, A., Alpaslan, M., Inal, A., Adak, M.S., Eraslan, F., Cicek, N. 2003. Effects of boron fertilization on the yield and some yield components of bread and durum wheat. Turkish Journal of Agriculture and Forestry, 27: 329-335.

Hussain, F., Yasin, M. 2004. Soil Fertility Monitoring and Management in Rice-Wheat System. Annual Report, LRRP, NARC, Islamabad, Pakistan, pp. 1-33.

Khan, R., Gurmani, A.H., Gurmani, A.R., Zia, M.S. 2006. Effect of boron application on rice yield under wheat rice system. International Journal of Agriculture and Biology, 8: 805-808.

Leghari, A.H., Laghari, G.M., Ansari, M.A., Mirjat, M.A., Laghari, U.A., Leghari, S.J., Laghari, A.H., Abbasi, Z.A. 2016. Effect of NPK and boron on growth and yield of wheat variety TJ-83 at Tandojam soil. Advances in Environmental Biology, 10: 209-216.

Malhi, S.S., Gan, Y., Raney, J.P. 2006. Yield, seed quality and boron uptake of Brassica oil seed crops in response to boron fertilization. Agronomy Journal, 99: 570-577.

Nadim, U.A., Awan, I.U., Baloch, M.S., Khan, N., Naveed, K. 2013. Micronutrient use efficiency in wheat as affected by different application methods. Pakistan Journal of Botany, 45: 887-892.

Nadim, M.A., Awan, I.U., Baloch, M.S., Khan, E.A., Naveed, K., Khan, M.A., Zubair, M., Hussain, N. 2011. Effect of micronutrients on growth and yield of wheat. Pakistan Journal of Agricultural Sciences,
48: 191-196.

Pasha, B.U., Ali, A., Saleem, M., Niazi, B.H. 2002. Role of boron for potassium/sodium ratio in sunflower under saline conditions. NARC, Islamabad, Pakistan, 25: 69-78.

Rashid, A., Yaseen, M., Ashraf, M., Mann, R.A. 2004. Boron deficiency in calcareous soil reduces rice yield and impairs grain quality. International Rice Research Notes, 29: 58-60.

Shahzad, K., Shehzad, M.A., Iqbal, M., Arif, M. 2012. Response of maize (Zea mays L.) genotypes to soil and foliar application of boron. Asian Journal of Pharmaceutical and Biological Research, 2: 65-72.

Shehzad, M.A., Maqsood, M. 2015. Integrated nitrogen and boron fertilization improves the productivity and oil quality of sunflower grown in a calcareous soil. Turkish Journal of Field Crops, 20: 213-222.

Steel, R., Torrie, J., Dickey, D. 1997. Principals and Procedures of Statistics. A Biometrical Approach, McGraw Hill Book Co. Inc., pp. 1409-1414, $3^{\text {rd }}$ edition, New York, USA.

Sultana, S., Muhmood, A., Shah, S.S.H., Saleem, I., Niaz, A., Ahmed, Z.A., Wakeel, A. 2015. Boron uptake, yield and quality of carrot (Daucus carota L.) in response to boron application. International Journal of Plant and Soil Science, 8: 1-5.

Tahir, M., Ali, A., Khalid, F., Naeem, M., Fiaz, N., Waseem, M. 2012. Effect of foliar applied boron application on growth, yield and quality of maize (Zea mays L.). Pakistan Journal of Scientific and Industrial Research, 55: 117-121.

Tahir, M., Tanveer, A., Shah, T.H., Fiaz, N., Wasaya, A. 2009. Yield response of wheat (Triticum aestivum L.) to boron application at different growth stages. Pakistan Journal of Life and Social Sciences, 7: 39-42.

Tombo, Y., Tombo, N., Cig, F., Erman, M., Celen, A.E. 2008. The effect of boron application on nutrient composition, yield and some yield components of barley (Hordeum vulgare L.). African Journal of Biotechnology, 7: 3255-3260.

Ziaeyan, A.H., Rajaie, M. 2009. Combined effect of zinc and boron on yield and nutrients accumulation in corn. International Journal of Plant Production, 3: $35-44$ 